\title{
Obesitaspreventie met pieken en dalen
}

\author{
Citation for published version (APA):
}

Kremers, S. P. J. (2014). Obesitaspreventie met pieken en dalen. Maastricht University. https://doi.org/10.26481/spe.20141017sk

Document status and date:

Published: 17/10/2014

DOI:

10.26481/spe.20141017sk

Document Version:

Publisher's PDF, also known as Version of record

\section{Please check the document version of this publication:}

- A submitted manuscript is the version of the article upon submission and before peer-review. There can be important differences between the submitted version and the official published version of record.

People interested in the research are advised to contact the author for the final version of the publication, or visit the DOI to the publisher's website.

- The final author version and the galley proof are versions of the publication after peer review.

- The final published version features the final layout of the paper including the volume, issue and page numbers.

Link to publication

\footnotetext{
General rights rights.

- You may freely distribute the URL identifying the publication in the public portal. please follow below link for the End User Agreement:

www.umlib.nl/taverne-license

Take down policy

If you believe that this document breaches copyright please contact us at:

repository@maastrichtuniversity.nl

providing details and we will investigate your claim.
}

Copyright and moral rights for the publications made accessible in the public portal are retained by the authors and/or other copyright owners and it is a condition of accessing publications that users recognise and abide by the legal requirements associated with these

- Users may download and print one copy of any publication from the public portal for the purpose of private study or research.

- You may not further distribute the material or use it for any profit-making activity or commercial gain

If the publication is distributed under the terms of Article $25 \mathrm{fa}$ of the Dutch Copyright Act, indicated by the "Taverne" license above, 
Prof. dr. Stef Kremers

Faculty of Health, Medicine and Life Sciences

\section{Obesitaspreventie met pieken en dalen}


Obesitaspreventie met pieken en dalen 


\section{Colophon}

Design \& print: Canon Business Services, Maastricht

ISBN: 9789056814434

NUR: 870

All rights reserved. No part of this publication may be reproduced, modified, stored in a retrieval system or made public without the prior written permission of the author or publisher. 


\section{Obesitaspreventie met pieken en dalen}

Inaugurele rede

benoemd in de faculteit Health, Medicine and Life Sciences tot bijzonder hoogleraar Preventie van Obesitas

Maastricht, 17 oktober 2014

Prof. dr. Stef Kremers 
Obesitaspreventie met pieken en dalen 
Mijnheer de Rector Magnificus, leden van het College van Toezicht, hooggeleerde gasten, beste collega's, familie, vrienden en overige aanwezigen, hartelijk dank voor uw komst naar Maastricht om mijn oratie aan te horen.

In deze lezing ga ik u een weergave geven van mijn vakgebied, preventie van obesitas. Ik zal het vakgebied proberen te duiden door aan te geven welke richting we trachten te geven aan het onderzoek en aan de praktijk. En ondertussen zult u misschien ook mij als persoon beter leren kennen, want ik heb geprobeerd om mijn verhaal dicht bij mezelf te houden.

Ik vertel u waarschijnlijk geen nieuws als ik zeg dat overgewicht steeds vaker voorkomt. Waar begin jaren '80 nog 1 op de 3 Nederlanders overgewicht had, is dat inmiddels bijna de helft. Het aantal mensen met extreem overgewicht, oftewel obesitas, is zelfs verdubbeld. Met aanzienlijke verhoging van risico's op negatieve gevolgen voor de gezondheid. $U$ heeft zich vast al eens afgevraagd wat nu de belangrijkste redenen van die toename in het voorkomen van overgewicht en obesitas zijn. En u heeft daar waarschijnlijk best wel ideeën bij. Volgens mij heeft iedereen daar wel ideeën bij, merk ik ook op feestjes en partijen. Dat is mooi, want het geeft aan dat het onderwerp leeft; in ieder geval voor de gemiddelde feestganger. Voordat ik ga proberen het nog meer te laten leven, neem ik u eerst even mee naar Waterval.

\section{Over Waterval en Gedragsverandering}

Kent u Waterval? Ik loop daar meestal heen als ik een stukje ga hardlopen. Het ligt op een steenworp afstand van Meerssen, en je waant je in Zuid-Duitsland. Tijdens zo'n tochtje gaan mijn gedachten wel eens terug naar onderzoek dat we in het verleden deden. Als ik dan terugkijk op het onderzoek dat we in de afgelopen 15 jaar hebben gedaan naar de oorzaken van de stijging van het voorkomen van overgewicht, dan is er een aantal duidelijke verschuivingen zichtbaar.

Vijttien jaar geleden waren we als het ging om gewichts beheersing vooral geïnteresseerd in intensief gedrag en grote gedragsveranderingen, zoals flink zware beweegprogramma's en studies naar diëten waarvan we ons later beseften dat ze onmogelijk op lange termijn vol te houden zijn. Gedrag dat het meest relevant is voor gewichtsstijging, is echter niet zozeer gedrag waar we heel intensief mee bezig zijn, maar het verschil 
wordt juist gemaakt door alledaagse bezigheden, die zich vaak uiten in gewoonten. Die alledaagse bezigheden zijn nu dus primair onderwerp van onderzoek. En in plaats van ons te richten op specifiek gedrag, zoals het eten van fast food of het gebruik van de auto in plaats van actievere vormen van transport, zijn we ons steeds meer gaan beseffen dat gedrag bestudeerd moet worden in termen van gedragspatronen, waarin verschillende gedragingen samenkomen, met een elkaar versterkende invloed op gewicht. En in plaats van alleen te kijken naar gedachten van mensen om te begrijpen hoe gedrag tot stand komt en beklijft, richten we ons onderzoek daar nu niet meer uitsluitend op, maar kijken we ook veel meer naar de rol die de omgeving speelt (De Bruijn, 2007; Kremers, 2010; Sleddens et al., 2013).

En het geheel aan factoren speelt hierbij op een ingewikkelde manier samen, dat we in ieder geval ten dele moeten begrijpen om op een succesvolle manier mensen te kunnen helpen om gemakkelijker hun gewicht op het door hen gewenste niveau te houden. Om mijn ideeën over dat samenspel beter te kunnen begrijpen, gaan we weer even naar Waterval.

Aan het eind van Waterval, je bent bijna in Ulestraten, ligt een flinke heuvel. Het heeft een aantal keren geduurd voordat ik dat ding zonder te stoppen kon beklimmen. Ik moest leren hoe de berg het beste te benaderen, maar moest ook in algemene zin fitter worden. Eerst maar eens tot de helft, daarna steeds een beetje verder. Er waren dagen dat het wat gemakkelijker ging dan andere; dat had te maken met het weer, maar soms ook met mijn eigen gesteldheid. Bovendien heeft die heuvel niet op alle plekken hetzelfde stijgingspercentage. Op sommige stukken is ie wat vlakker, en daarna een stuk steiler zodat de beklimming met horten en stoten lijkt te gaan. Op een gegeven moment lukte het; ik was boven zonder te stoppen, en die heerlijke weg daarna (eerst vrij stijl naar beneden, daarna kilometers vals plat) leek als vanzelf te gaan.

Waarom vertel ik u dit nou? Wel, mijn ervaringen met die heuvel in Waterval lijken erg op ervaringen van mensen die gezonder willen leven. Mensen die de dagelijkse patronen willen doorbreken, hun gewoonten willen veranderen. Dan is het vaak ploeteren, met faalervaringen, en opnieuw proberen. De ene dag gaat het beter dan de andere (soms te maken met de omstandigheden, en soms met eigen gesteldheid). Het proces gaat niet geleidelijk maar eerder met horten en stoten; 
met pieken en dalen. Maar als het dan lukt, zo vertellen bijvoorbeeld veel mensen die succesvol blijvend $10 \%$ van hun lichaamsgewicht zijn kwijtgeraakt, komt er een punt waarbij een nieuwe balans is gevonden en het minder moeite kost om de nieuwe gedragspatronen vol te houden. Overigens spreken mensen die zo'n besluit hebben genomen om een gezondere leefstijl aan te nemen, vaak ook in termen die alles behalve geleidelijkheid impliceren. Ik citeer: "Ik deed het gewoon"."Ineens viel het kwartje”. "Jarenlang aangeklooid, en toen vielen de puzzelstukjes ineens op hun plek". In de populaire literatuur is dit fenomeen herkend; het wordt het 'tipping point' genoemd. Het omslagpunt. Een punt dat je bereikt aan de top van een heuvel, en waarna alles, op de weg naar beneden ineens een stuk gemakkelijker gaat (Scheffer, 2010). Op dat punt heb je dan ook maar een klein duwtje nodig om in beweging te komen, om tot aanpassingen in je leefstijl te komen. Dit beeld verklaart ook waarom gezondheidsbevorderende interventies bij veel mensen niet tot gewenste effecten leiden. Mensen op ieder ander punt in de beklimming dan het tipping point hebben vaak aan een kort of weinig intensief programma niet genoeg ondersteuning om de piek te overwinnen. Flinke duwtjes veroorzaken dan niet of nauwelijks beweging.

Nou wil het geval dat de onderzoeksbenaderingen in het veld van obesitaspreventie, maar ook breder in de gezondheidsbevordering en gezondheidspsychologie een wat ander beeld lijken te hebben van gedrag en gedragsverandering dan een heuvel. Dat lijkt meer op een biljartlaken. Dat is wel te verklaren. We zijn van nature geneigd om rechtlijnige verbanden te leggen tussen oorzaak en gevolg in de dingen en het gedrag dat we om ons heen zien. Dat maakt de wereld immers overzichtelijk. Zij is dik, dus zij is lui. We verliezen de wedstrijd, dus we hebben een slechte bondscoach. Hij heeft een jurk aan, dus hij zal wel slim zijn. We geven haar een duw, een stoot of een nudge, dus dan zal ze wel in beweging komen. Op een vergelijkbare manier zijn we geneigd om de dingen die we zien uit de context te halen. Eens kijken of een proefpersoon in een laboratorium meer M\&M's eet als het bakje dichterbij hem staat. Nuttig om te weten, zeker; zulk onderzoek is ook echt nodig om de rol van specifieke elementen in de omgeving op ons gedrag beter te begrijpen, maar niemand woont in een laboratorium. Tenzij je een labrador bent op de Universiteit Maastricht, natuurlijk. In de echte wereld zijn er een heleboel andere factoren die ook mede bepalen hoeveel $M \& M s$ iemand in een bepaalde situatie eet. 
Als je die bergbeklimming en afdaling in het perspectief plaatst van een mensenleven, dan zou je Mount Waterval dus eigenlijk in een groter berglandschap moeten plaatsen. Het besef dat we op een andere manier moeten kijken naar gedrag begint de laatste jaren in te dalen in het onderzoek in het kader van preventie van obesitas.
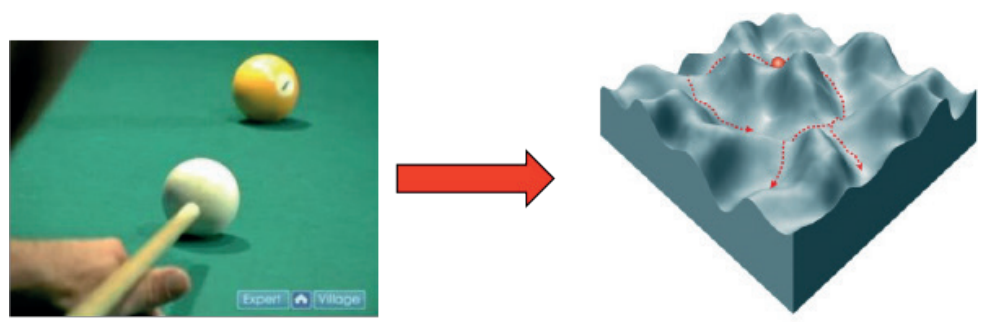

In plaats van het gedrag te beschouwen als een simpel, geleidelijk en lineair resultaat van specifieke invloeden, wordt het in toenemende mate gezien als een uiting van het samenspel tussen invloeden, dat veel meer lijkt op een berglandschap dan op een biljartlaken. Het leven is als een berglandschap, met pieken en dalen. Die moet ik even uitleggen. Er is vandaag ook pers aanwezig en in een gesprek met de afdeling communicatie van de universiteit werd mij verteld dat voor een goede weergave van je boodschap je eigenlijk het beste zelf de kop kunt aanleveren. Dus bij dezen; u kunt meeschrijven.

Die metafoor die ik probeer te zoeken in zo'n berglandschap heb ik overigens niet zelf bedacht. De origine ervan gaat terug naar het exploratieve werk van bioloog C.H. Waddington (Waddington, 1957). Dat zogenaamde attractor landschap is een begrip in onderzoeksvelden waarin zogenaamde systeemtheorieën worden gebruikt om problemen op te lossen die niet lineair van aard zijn. En een heleboel problemen zijn niet lineair van aard. Dus worden systeemtheorieën in een breed scala aan wetenschapsgebieden succesvol toegepast, zoals in de scheikunde, natuurkunde, celbiologie en neurowetenschappen (Thelen \& Smith, 2006). Keer op keer blijkt dat dat balletje zich het prettigst voelt in een vallei. Daar ligt het lekker rustig. Vertaald naar menselijk gedrag betekent dat: geen verandering. Dingen doen die je altijd doet. Gewoonten. Doorbreken van die gewoonten kost moeite; het balletje moet immers in beweging komen. Om oude gewoonten af te leren en nieuwe aan te leren, zal een piek moeten worden overwonnen, voordat het balletje relatief eenvoudig rolt naar een volgende vallei. 


\section{Obesitaspreventie in een landschap van pieken en dalen}

Ik heb misschien gemakkelijk praten met de geslaagde beklimming van die heuvel in Waterval. Ik heb namelijk wel iets van externe motivatie in mijn thuissituatie. Ik heb namelijk een vrouw die regelmatig tennist of met Shaun T staat te 'hip-hop-absen'. Flinke concurrentie dus. Ik moet natuurlijk een beetje bijblijven om zo iemand partij te kunnen geven. Dus druk van buitenaf, en, toegegeven, ook wel een beetje steun. Maar het belangrijkste is dat ik van jongs af aan sportief ben geweest. Van jongs af aan heb ik de lol van sporten geleerd en meegekregen, ik heb techniek en fysiek ontwikkeld die die heuvel voor mij relatief vlak maakt. Zeker als je dat vergelijkt met mensen die we bijvoorbeeld tegenkomen in het kader van leefstijlinterventies in de eerstelijnsgezondheidszorg. Zij zijn in een vicieuze cirkel terechtgekomen waarbij hun fysieke gesteldheid bewegingsarmoede in de hand heeft gewerkt, hun emotionele gesteldheid heeft geleid tot de consumptie van energiedichte voeding, hetgeen leidt tot een nog slechtere fysieke gesteldheid. Bovendien hebben ze vaak veel faalervaringen gehad bij eerdere pogingen om af te vallen. Niet in de laatste plaats omdat goedbedoelende zorgverleners hen een nieuw onhaalbaar leefpatroon hebben opgelegd dat weliswaar op de korte termijn goed te doen is, maar waar men uiteindelijk toch op het gezicht is gegaan. Men wordt als het ware getackled. De intrinsieke motivatie, de lol, om te bewegen en gezond te eten is dan tot een nulpunt gedaald. En die berg wordt dan oneindig hoog en onnoemelijk stijl. Waar het mij nog in mijn eentje lukte om mijn programma zodanig op te stellen om de Mount Waterval te overwinnen, hebben deze mensen vaak meer nodig dan een goed advies om terugval in oude gewoonten te voorkomen.

Als die duwtjes in de vorm van voorlichting en counseling niet altijd werken, wat is dan de link tussen dat landschap met pieken en dalen en obesitaspreventie? Wel, met preventie kunnen we die berg minder stijl maken (Milstein, 2006).

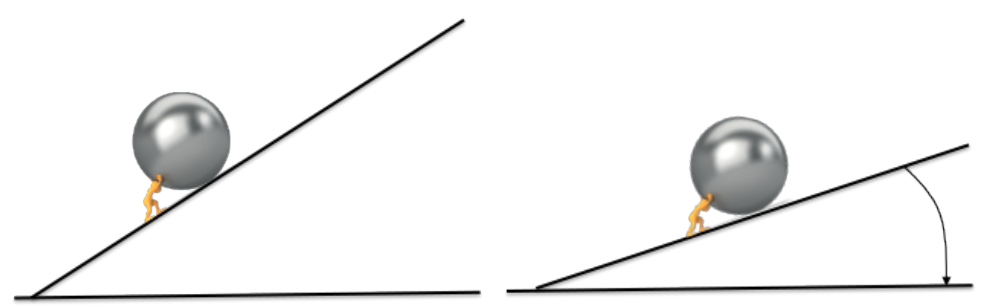


We kunnen de omgeving zodanig inrichten dat mensen niet zoveel moeite hoeven te doen om gezonde gedragskeuzes te maken en vol te houden. "De gezonde keuze de gemakkelijkste keuze maken" is een gevleugelde term die daarop slaat. Maar ik noemde zojuist niet voor niets het feit dat ik jong heb geleerd om actief te zijn. Veel inspanningen binnen obesitaspreventie zijn gericht op jonge kinderen. Jong geleerd is oud gedaan. Kinderen die gezond gedrag aanleren hebben het op latere leeftijd gemakkelijker om dat ook te doen. De berg wordt een heuveltje. In feite wordt het landschap waar een individu zich in zijn leven doorheen verplaatst al op jonge leeftijd in de basis gevormd. Uiteraard is de definitieve vorm afhankelijk van allerlei keuzes die het individu in het leven maakt (of hem overkomen), maar de contouren staan vast. Een kind dat opgroeit in een ongezonde omgeving schept contou ren van een landschap dat lijkt op de Pyreneeën, terwijl een kind dat opgroeit in een gezonde omgeving wordt geplaatst in een landschap dat lijkt op ZuidLimburg. Tja, dan lijkt de keuze gemakkelijk. Grapje natuurlijk, maar het geeft wel aan waarom we het zo belangrijk vinden om in de preventie van obesitas veel aandacht te geven aan de jeugd.

Wie bepaalt dan in essentie de contouren van dat landschap voor kinderen? De ouders. Vandaar ook dat wij in ons onderzoek in het kader van preventie van obesitas bij kinderen zwaar inzetten op de rol van die ouders (Gubbels, 2010; Sleddens, 2013; Rodenburg, 2013; Gerards, 2014). Ouders willen het beste voor hun kind, en we proberen inzicht te krijgen in hoe we ouders het beste kunnen helpen bij de vorming van die gezonde omgeving. Daarvoor proberen we in kaart te brengen wat ouders kunnen doen om het voedings- en bewegingsgedrag van hun kinderen gunstig, en blijvend, te beïnvloeden. Om zodoende programma's te kunnen verbeteren om ouders, bijvoorbeeld van kinderen met beginnend overgewicht, te helpen bij het ondersteunen van hun kind naar gezonde gedragskeuzes. En alle kleine beetjes helpen dan.

Daarmee kom ik op een punt waarikal tijden tegen ageer, en het is er eentje waarvan ik moet toegeven dat ik die ook bij gezondheidsbevorderaars zie: de neiging om normatief te denken. Je hebt goed gedrag en je hebt slecht gedrag, ingegeven door normen die wij als wetenschappers daar zelf over hebben opgesteld. Gemiddeld 35 minuten per dag bewegen? Prima, niets meer aan doen. Gemiddeld 25 minuten per dag bewegen? Slecht (want niet een half uur). Waarom zou het niet hartstikke goed zijn van iemand die ervoor heeft gekozen om voortaan de fiets naar het werk te pakken en een inactief bestaan in te ruilen voor 25 minuten beweging 
per dag? En waarom zou het niet goed zijn voor iemand die 35 minuten per dag beweegt om positieve veranderingen in zijn leefstijl aan te brengen? Hetzelfde geldt voor de consumptie van die ene dagelijkse banaan van iemand die jarenlang had afgeleerd om überhaupt fruit te eten. Op het gebied van preventie van obesitas geldt: Normen zijn

\section{waardeloos.}

\section{Hogere orde moderatie}

De omgeving waarin wij gedragskeuzes maken, de context, verschilt van persoon tot persoon. In gedragswetenschappelijke termen hebben we het dan over moderatoren. Onderzoek dat we uitvoeren, gericht op die moderatoren, probeert in kaart te brengen welke factoren de stijgingsgraad van de berg bepalen. Onderzoek naar de modererende rol van contextuele factoren is niet eenvoudig. Laat staan het uitleggen daarvan in een oratie, maar ik ga het toch proberen. Waarschijnlijk is de complexiteit van de materie overigens onderdeel van de oorzaak van een schrijnend tekort aan onderzoek op dit gebied. Daar willen wij verandering in brengen. Het gaat hier om zogenaamde hogere orde moderatie; een van de basisaannames van ecologische theorieën van gedrag (Friedman \& Wachs, 1999). Hogere orde moderatie houdt in dat factoren die verder van een persoon staan, de impact van invloeden die dichter bij de persoon staan kunnen beïnvloeden. Ingewikkeld. Geen nood; Master studenten hebben meer dan de paar minuten die ik hieraan nu ga besteden nodig om het te begrijpen, maar toch ga ik mijn best doen om het principe van hogere orde moderatie te verduidelijken, vooral ook omdat het een heel belangrijk proces is om de obesitasproblematiek te begrijpen en vooral om er wat aan te doen.

Hogere orde moderatie houdt dus in dat factoren die verder van een persoon staan, de impact van invloeden die dichter bij de persoon staan kunnen beïnvloeden. Stel, $u$ bent ouder van een kind van 8 jaar die $u$ minder gesuikerde dranken wilt laten drinken. $U$ dacht altijd dat dat pakje Wicky dat $u$ aan uw kind meegaf naar school best gezond was; er stonden immers vruchtjes op de verpakking. Inmiddels weet $u$ beter, en $u$ besluit om dat pakje te vervangen door een flesje water (immers, de enige reden om uw kind drank mee te geven naar school is dat het voldoende vocht binnen krijgt. Wel, dat zit in water). $U$ komt erachter dat dat op weerstand stuit van uw kind. $U$ zult hier moeten putten uit uw opvoedingsvaardigheden om deze nieuwe regel door te voeren. Wat gebeurt er? Uw kind gaat met het water naar school, en vindt daar haar 
vriendinnetje, we noemen haar even Kim, met een pakje Wicky. En uw kind komt thuis met veel weerzin tegen het meegenomen water; "dat doe ik dus echt niet meer". Het was toch wel gemakkelijker geweest als de ouders van Kim hetzelfde waterbeleid hadden ingesteld. Welnu, de regels van de ouders van Kim zijn een hogere orde moderator. De ouders van Kim staan wat verder van uw kind af, maar bepalen toch mede het succes van uw gedrag. De school van uw kind is dus ook zo'n factor. Uw gedrag zou waarschijnlijk veel succesvoller zijn als de school zou besluiten om een waterbeleid in te stellen. De school is in dit geval dus ook zo'n hogere orde moderator. Een hogere orde moderator kan dus de stijgingsgraad van een berg beïnvloeden. Als de context meewerkt wordt de berg minder stijl.

Als de context meewerkt wordt de berg minder stijl. Nu wil echter het vervelende geval dat die context meestal NIET meewerkt. Het stikt in het obesitasveld van de hogere orde moderatoren. En de meeste daarvan maken de berg alleen maar steiler in plaats van vlakker... In de literatuur wordt dat ook wel de obesogene omgeving genoemd (Egger \& Swinburn, 1997). Een omgeving die ervoor zorgt dat de gemakkelijkste keuze de ongezonde keuze is. Dan hebben we het bijvoorbeeld over scholen zonder gezondheidsbeleid, gebrek aan vakleerkrachten voor de gymles, maar ook aan de McDonald's op de hoek, energiedichte voeding op ooghoogte in de supermarkt, misleidende labelling van voedingsproducten, en gebrek aan stimulerende beweegomgevingen.

Een belangrijk doel van obesitaspreventie is volgens mij dus ook om die hogere orde moderatoren gunstig te beïnvloeden. We moeten proberen het attractorlandschap bij te schaven; om het ploeteren te verminderen, gunstige automatismen te bevorderen, het tipping point dichterbij te brengen. En dan te bestuderen welke impact dat landschap, die context, heeft op gedrag.

En wat blijkt uit dergelijke studies? We kunnen die context het beste beschrijven als 'wicked' (Rittel \& Webber, 1973). Een context die wicked is, is moeilijk te 'vatten', terug te brengen tot één of slechts enkele doorslaggevende factoren. Dat is typisch voor de obesogene omgeving. Je wordt niet dik van een onveilige speelplek. Van het ontbreken van een gezond trakteerbeleid op school. Of van een fastfood restaurant in de buurt. Maar het gaat juist om dat samenspel tussen al die factoren. En dat maakt het wel ingewikkeld voor besluitvormers in het politieke 
domein (Hendriks et al., 2013). De persoon die wat te zeggen heeft over de vestiging van fastfood restaurants, heeft totaal geen zeggenschap over veiligheid in de wijk, en ook niet over het trakteerbeleid op school. Deze gedeelde verantwoordelijkheid leidt niet zelden, maar ook verklaarbaar, tot gebrek aan visie, daadkracht, en tot besluiteloosheid. Voordat ik u nog verder het dal in praat, stop ik hier even met de belofte dat ik u straks mijn ideeën geef over hoe het beleid ten aanzien van de preventie van obesitas zou kunnen worden verbeterd.

\section{Pieken en dalen in het onderwijs}

Ik noemde eerder al de termen intrinsieke motivatie en extrinsieke motivatie. De manier waarop iemand gemotiveerd is om gedrag te veranderen, bepaalt namelijk in grote mate of men erin slaagt om gedragsverandering vol te houden. Het gaat niet zozeer om hoeveel (kwantiteit dus, 'lineair'), maar om hoe men gemotiveerd is om gedrag te veranderen. We hebben bijvoorbeeld laten zien dat geuite kwantiteit van motivatie ('ja dokter ik ben heel gemotiveerd om gezonder te gaan leven') gedragsbehoud veel slechter (lees: niet) voorspelt dan een veel minder 'hoge', maar wel kwalitatief betere motivatie ('ik zou heel veel genoegen halen uit een gezondere leefstijl, maar ik twijfel of het me lukt') (Helmink et al., 2013; Rutten et al., 2014).

Dit laatste type persoon kan dan meer gebruiken dan alleen een goed advies, waarover ik het eerder had. In de praktijk testen we nu of een zogenaamde leefstijlcoach daarin zou kunnen slagen. Hopelijk verbaast het $u$, na het voorgaande, niet als ik zeg dat zo'n leefstijlcoach meer moet zijn dan iemand die goed is in, laat ik het maar even 'traditionele counseling' noemen. Natuurlijk, de coachingstijl is een kerncompetentie die belangrijk is om mensen te ondersteunen bij leefstijlverandering, maar dat is lang niet alles. Een leefstijlcoach die te maken heeft met cliënten die zich bewegen (of juist niet bewegen) in een enorm bergachtig landschap (want dat is typisch het geval bij mensen met overgewicht), moet ook andere capaciteiten hebben om de cliënt te ondersteunen in de beklimming. Een kleine greep uit de eerste resultaten van een studie die we nu in opdracht van zorgverzekeraar CZ uitvoeren: motiverende gespreksvaardigheden, sociale omgeving kunnen mobiliseren, de link tussen het zorgdomein en het publieke domein kunnen leggen, contacten zoeken en onderhouden met lokale beweegaanbieders, gemeente, diëtisten, huisartsen. Vaardigheden die niet in de traditionele training van hulpverleners zitten. 
Daarin dienen, door de erkenning van de multifactoriële aard van de obesitasproblematiek, hoogstnoodzakelijke veranderingen te komen. Mensen die zich in het zorgdomein gaan bevinden dienen te worden getraind in het verbeteren van inzicht in en het in kaart brengen van het attractorlandschap van een cliënt, en in vaardigheden om relevante spelers in het publieke domein te identificeren en benaderen. En training van mensen die worden opgeleid tot een functie in het publieke domein om gezondheidsgedrag en gezondheidsbevorderende programma's te kunnen beschouwen als onderdeel van het systeem waarin zij zich bewegen, maar ook om samenwerking te bevorderen, in ondernemerschap.Vandaar ook dat ik blij ben dat ik het onderzoek binnen mijn leerstoel mag uitdragen in verschillende bachelor en masterstudies van de Universiteit Maastricht. Op dit moment leveren we een bijdrage aan de bacheloropleidingen binnen Gezondheidswetenschappen en Geneeskunde, en binnen de masteropleidingen Health Education and Promotion, Work Health and Career, en Health Food Innovation Management door middel van bijdragen aan het regulier onderwijs en begeleiden van stages, en door middel van gastcolleges bij andere onderwijsinstituten. Het zal u niet verbazen dat ik in dat onderwijs het belang van een systeembenadering, maar ook van samenwerking en integratie benadruk.

Dat brengt me bij de paden die we willen gaan bewandelen binnen de leerstoelgroep. Ten aanzien van het onderwijs heb ik $u$ kort mijn ideeën geschetst. Ik kan hier uiteraard niet uitputtend zijn over de andere paden, maar wil wel graag in het laatste deel van mijn rede enkele zwaartepunten benoemen voor zowel onderzoek, beleid als praktijk.

\section{Integrale aanpak}

De eerste is de zogenaamde integrale aanpak. Wat ik in de praktijk vaak zie is dat stand-alone programma's, soms hele mooie programma's, worden geïmplementeerd in een setting, zonder dat daarbij wordt aangehaakt vanuit andere settings (Kremers et al., 2008). Geïsoleerde activiteiten vinden plaats zonder mogelijkheden om door te stromen naar verbredings- of verdiepingsactiviteiten. Versnippering dus. Dat is schieten met losse flodders. Ik zeg altijd maar zo: Versnippering is als confetti met carnaval: Je hebt er even plezier van, maar aan het eind van de avond stinkt het naar bier.

Voorkomen van versnippering vereist visie op overkoepelend vlak: structurele en planmatige agendering is nodig om te voorkomen 
dat uitvoerders het idee krijgen dat inspanningen over een paar jaar weer voor niets zijn geweest. We zien dat vaak wordt vervallen in de implementatie van impulssubsidies. Een kortstondige boost met een duidelijke einddatum. Dat is geen stimulering van een integrale aanpak (die kost namelijk tijd en investering), maar dat is stimulering van versnipperde stand-alone activiteiten. Even een kortdurende piek, waarna het balletje weer terugrolt naar het dal: alles gebeurt weer op de oude manier.

Om een geïntegreerde en integrale preventie van obesitas te bewerkstelligen zal samenwerking gezocht moeten worden tussen relevante partijen in het gezondheidsdomein, maar ook daarbuiten. Publiek-private samenwerking valt daar wat mij betreft ook onder. Elkaars kennis, vaardigheden en mogelijkheden moeten worden benut. Binnen het Consortium Integrale Aanpak Overgewicht doen we onderzoek naar bevorderende en belemmerende factoren in dit kader ten aanzien van preventie van obesitas bij jeugd (Van Koperen et al., 2014). En als daar iets duidelijk uit blijkt is dat integrale aanpak niet eenvoudig is. Maar we zien ook pareltjes die in meerdere opzichten positief stemmen over de aanpak. Gebaseerd op een mooi voorbeeld in Frankrijk (Romon et al., 2009), EPODE, wordt nu in Nederland in een toenemend aantal gemeenten gewerkt volgens de JOGG methode. JOGG staat voor Jongeren op Gezond Gewicht, en ondersteunt gemeenten in het proces om tot de hoognodige integrale samenwerking te komen.

De resultaten van EPODE zijn even verbluffend als inspirerend. Maar ook in Nederland wordt nu in een paar gemeentes waar relatief zwaar wordt ingezet op de integrale aanpak van overgewicht mooie resultaten geboekt. In Zwolle, Utrecht en Dordrecht, bijvoorbeeld, is het gelukt om een afname in het percentage kinderen met overgewicht te bewerkstelligen. Dat lijkt dus op een trendbreuk en stemt hoopvol voor de werkzaamheid van de benadering die men heeft gekozen.

\section{Verbinding tussen preventie en zorg}

De integrale aanpak is dus zo'n bergpad dat we zeker verder gaan bewandelen. Een andere, daaraan gerelateerde, is de verbinding tussen preventie en zorg. Preventie en zorg worden ten onrechte gezien als twee afzonderlijke werelden. Nu hebben we dat in Maastricht onderkend, hetgeen onder ander heeft geleid tot een fusie tussen de faculteiten Gezondheidswetenschappen en Geneeskunde alsmede de inkadering 
van zowel preventie als zorg binnen het Maastricht Universitair Medisch Centrum+. Dat laatste is nog niet het grootse succesverhaal dat ik ken, maar het is een stap in de goede richting, zeker voor wat betreft de preventie van obesitas. Het vakgebied preventie van obesitas laat zich immers niet vangen in het hokje preventie of het hokje zorg. Het kan zich namelijk uiten in alle vormen van de preventiepiramide. Universele preventie is gericht op de algemene populatie. Selectieve obesitaspreventie is gericht op een deel van de bevolking met verhoogd risico op het ontwikkelen van obesitas. Je kunt hierbij bijvoorbeeld denken aan programma's die speciaal zijn gericht op de zogenaamde achterstandswijken. Geïndiceerde preventie is gericht op individuen die bijvoorbeeld wel overgewicht hebben, maar geen obesitas. Terwijl zorggerichte preventie zich bijvoorbeeld in een ziekenhuissetting richt op het monitoren en behandelen van mensen met obesitas.

Voor elke willekeurige populatie, neem een schoolklas, zou een sluitende ketenaanpak beschikbaar moeten zijn. Universele preventie, bijvoorbeeld in de vorm van een schoolprogramma; selectieve preventie, gericht op kinderen die wonen in een achterstandswijk; geïndiceerde preventie, gericht op ouders van kinderen met overgewicht die zich hebben aangemeld voor een groepsinterventie; zorggerelateerde preventie vanuit een kinderobesitas kliniek. Let wel, deze preventieve activiteiten zijn effectiever en efficiënter als bij iedere vorm van preventie verbindingen worden gelegd tussen het publieke domein en het zorgdomein, zoals ik eerder heb benoemd toen ik de kerncompetenties van de leefstijlcoach besprak.

\section{Onderzoeksbenadering}

Tenslotte wil ik nog even terugkomen op de onderzoeksbenadering die we toepassen als invulling van mijn leerstoel. De onderzoeksbenadering die we hebben binnen onze leerstoelgroep is voortdurend in ontwikkeling geweest (Kremers et al., 2006; Kremers, 2010). Ik ben er blij om, en trots op, dat wij op veel van de gebieden die ik aan het begin van mijn rede heb geschetst, internationaal worden gezien als voorlopers. Dat blijkt bijvoorbeeld uit reacties op de werkvloer, maar gelukkig ook uit citatieen downloadgegevens van artikelen die we hebben gepubliceerd over onze benadering en het feit dat het op veel plekken wordt gebruikt als onderwijsmateriaal. Maar we zijn er nog niet. Ik hoop dat ik in het voorgaande duidelijk heb kunnen maken dat er een noodzaak is tot een sterkere verschuiving in de richting van een focus op moderatoren 
(Gubbels et al., 2014). Maar ook van kwantiteit van motivatie naar kwaliteit van motivatie, en onderzoek naar systemen. We zijn aardig op dreef, maar er zijn ook nog flink wat Pieken te overwinnen in onderzoeksland.

Waar we nog winst kunnen behalen is het leggen van dwarsverbanden naar andere onderzoekstradities. Dan denkik bijvoorbeeld aan studies die we uitgevoerd hebben en uitvoeren waarin we dwarsverbanden leggen met onderzoekstradities binnen de epidemiologie, sociale geografie, psychologie, humane biologie, geneeskunde, zorg voor chronisch zieken en bewegingswetenschappen. Maar ik denk vooral ook aan plannen die we hebben om deze lijn door te trekken naar neuropsychologie, ontwikkelingspsychologie en systeemonderzoek. En aan het voortzetten van bestaande samenwerkingsverbanden met andere universiteiten en hogescholen, Academische Werkplaatsen, onderzoeksinstituten, private partners, verzekeraars, en onderzoeks- en kennisinstituten. Ik lijk, staand voor deze slide met logo's, een beetje op de voetballer die na de wedstrijd voor de camera wordt geïnterviewd met alle sponsors op de achtergrond, besef ik mij nu. Nou ja, dat was ook ooit een droom, dus die pik ik maar mooi even mee. Het is eigenlijk een slide van niks, moet ik zeggen, veel te vol en het heeft de schijn van namedropping en slijmerij. Bovendien zit er nu vast iemand in de zaal tevergeefs te zoeken naar zijn logo. Sorry daarvoor, hierbij meteen een disclaimer dat hij niet compleet is. Gezien de multifactoriële aard van obesitas en de integrale aanpak ervan die ik voorsta, is het aan de andere kant ook wel logisch dat die slide zo vol staat; iedereen kan vanuit zijn achtergrond een bijdrage leveren aan de positieve beïnvloeding van het systeem.

Daarbij moeten we de stap maken van systeemdenken naar systeemdoen. Ik denk daarbij aan modelleringsstudies en de toepassing van nonlineaire analysemethoden binnen het onderzoek dat we doen. Analysemethoden die tipping points kunnen detecteren, en kunnen modelleren dat kleine veranderingen in het systeem kunnen leiden tot grote gedragseffecten; en andersom: grote veranderingen die geen effect hebben op gedragskeuzes. Daarbij moeten we ook groter durven denken en systeembenaderingen ook echt uitvoeren en toetsen. Onderzoek dient dan bij voorkeur te worden uitgevoerd op 'real life' interventies, dus zonder bemoeienis en controle door onderzoekers en zonder een dwangmatige keuze voor 'ideale' designs. In plaats daarvan moeten we ons richten op actiebegeleidende studies met 'optimale' designs. Dan 
kun je denken aan natuurlijke experimenten, maar ook bijvoorbeeld aan toetsing van de kracht van de geïntegreerde systeembenadering versus de versnippering of losse flodders waar ik het eerder over had. En er gebeurt echt al het een en ander in de praktijk dat volledig valt binnen de kaders van mijn droom over optimale preventie van obesitas. In ieder geval op papier ziet dat er gedegen uit, maar het zou zo jammer zijn als we niets van kunnen leren van de implementatiepraktijk door het identificeren van valkuilen, barrières en pareltjes door middel van onderzoek. Neem bijvoorbeeld JOGG. Eén van de pijlers van JOGG is evaluatie, het is een voorwaarde om te evalueren als je met JOGG in zee gaat. Het is alleen zo jammer om te zien dat bij veel gemeenten die evaluatie wordt gezien als een sluitpost op de begroting, en op die manier dus inspanningen in het kader van de integrale aanpak van obesitas niet op waarde kunnen worden geschat en dat er niet van de pieken en dalen die men tegenkomt kan worden geleerd. 


\section{Dankwoord}

Ik wil graag een woord van dank uitspreken aan een ieder die het mogelijk heeft gemaakt dat ik hier kan en mag staan. In het bijzonder wil ik noemen: De leden van het College van Bestuur van deze Universiteit, van de raad van bestu ur van het MUMC+, en van het College van Toezicht. Ik dank hen zeer voor het door hen in mij gestelde vertrouwen. Twee personen wil ik daar specifiek in noemen: Nanne de Vries en Annemie Schols. Nanne, als vakgroepvoorzitter en mentor heb je me altijd heel goed de weg gewezen binnen en buiten de muren van de universiteit. Ik heb altijd veel vertrouwen van jou gevoeld in de keuzes die ik maakte en kon altijd een beroep op je doen voor advies. En dat geldt ook voor Annemie Schols. Ik heb enorme bewondering voor de manier waarop jij het onderzoeksinstituut NUTRIM aanstuurt, en ben heel blij en dankbaar voor je steun bij mijn onderzoek en bij mijn persoonlijke ontwikkeling. Daarbij wil ik ook meteen Sef Janssen en Fred Gorissen noemen als steun en toeverlaat voor alles dat met geld te maken heeft. Wat geeft het een fijn gevoel als je zaken waar je totaal geen verstand van hebt kunt neerleggen bij mensen die in ieder geval net doen alsof zij dat wel hebben.

Mijn mentoren van het eerste uur wil ik zeker ook expliciet benoemen. Aart Mudde en Hein de Vries, mijn promotoren. Hein, bedankt voor het vertrouwen dat je in me had en de potentie die je blijkbaar in me zag toen ik als assistent op de vakgroep rondliep. Aart, van jou het ik misschien nog wel het meeste geleerd over het doen van onderzoek in de periode dat ik echt van niets wist.

Hans Brug wil ik bedanken voor het introduceren van mij in dit enorm enerverende onderzoeksveld, en voor de autonomie die ik al snel kreeg om mijn eigen pad vorm te geven. Tommy Visscher, als mijn eerste partner op dit gebied, wil ik ook heel graag bedanken. Tommy, ik heb vakinhoudelijk heel veel van je mogen leren, soms zittend aan de bar, soms hangend aan de bar, maar gelukkig ook vaak staand aan de bar (want dat is toch een stuk gezonder). Ik zal nooit onze bijzondere en leerzame bezoeken vergeten die we regelmatig mochten afleggen aan professor Daan Kromhout. Maar ook de lange dagen die we maakten bij het schrijven van subsidieaanvragen, voortgangsverslagen en wetenschappelijke rapporten en papers zullen me altijd bijblijven. Goede Vrijdag zal voor mij altijd verbonden blijven aan jou. Naast je aanstekelijk enthousiasme en belabberde voetbalkennis. 
Er zijn veel mensen die ik in de loop van de jaren tegen ben gekomen en dank ben verschuldigd. Ik ga niet beginnen aan het opnoemen van zo'n lijst, omdat ik waarschijnlijk mensen ga vergeten of mensen alleen uit fatsoen ga noemen. Dat doe ik dus niet, maar ik wil wel expliciet alle promovendi noemen die ik als co-promotor of promotor heb mogen begeleiden of nog steeds begeleid: Gert-Jan de Bruijn, Lydia Kwak, Jessica Gubbels, Judith Helmink, Ester Sleddens, Gerda Rodenburg, Daniela Schulz, Sanne Gerards, Jessie Meis, Lieke Raaijmakers, AnnaMarie Hendriks, Dave Van Kann, Dorus Gevers, Victor Akande, Teun Remmers, Celeste van Rinsum, Anwar Alsharif, Nina Bartelink. Jullie hebben allemaal substantieel bijgedragen aan waar we nu staan als groep. Wat ben ik blij met jullie. En het mag duidelijk zijn dat in tegenstelling tot de gangbare gedachte en het beeld dat ik blijkbaar heb opgebouwd door de jaren heen, en even voor de duidelijkheid: deze mensen zijn lang niet allemaal vrouw én lang niet allemaal blond.

En de mensen met wie ik die begeleiding heb gedaan en doe wil ik ook hartelijk danken: Patricia van Assema, Marleen van Baak, Hans Brug, Pieter Dagnelie, Dick Ettema, Sanne Gerards, len van de Goor, Jessica Gubbels, Maria Jansen, Willem van Mechelen, Ree Meertens, Dike van de Mheen, Jascha de Nooijer, Anke Oenema, Rob Ruiter, Geert Rutten, Hans Savelberg, Annemie Schols, Carel Thijs, Hein de Vries, Nanne de Vries, Sanne de Vries.

Verder dank ik alle collega's van de vakgroep Gezondheidsbevordering, in het bijzonder de ondersteuning die ik kreeg van Marja Vissers en krijg van Patricia von Schenckendorff. En de nooit haperende technische ondersteuning van Leon Kolenburg, binnen, maar ook buiten normale werkuren.

Tot slot nog het belangrijkste woord van dank aan mijn familie. Pap en mam, jullie zijn enorm belangrijk voor mij en het feit dat ik hier nu sta heb ik voor een heel groot deel aan jullie te danken. Jullie hebben me gevormd en altijd ondersteund en (vaak letterlijk) aangemoedigd. Mam, ik weet als onderzoeker dat zorgzaamheid een belangrijke factor is in de opvoeding, maar jij hebt die factor echt een nieuwe dimensie gegeven. Daar heb ik echt heel veel respect voor. Pap, je bent echt een voorbeeld voor me. In het werk, bijvoorbeeld in de manier van omgang met collega's, maar je hebt me ook van jongs af aan laten zien wat écht hard werken is. Maar vooral ook in het leven: het belang van familie, en van plezier in sport (doen én kijken), in goede en slechte tijden. 
En dan heb ik ook nog eens het geluk van twee hele fijne schoonouders.

Mijn broers, Bart en Paul, ik vind het bijzonder dat we alle drie een hele andere kant op gegaan zijn, maar toch veel raakvlakken hebben, niet toevallig precies op die vlakken waarvoor ik net ons pap en ons mam bedankte. We kennen elkaar zo goed, dat we vaak maar een half woord nodig hebben, of soms nog niet eens en meteen overstappen naar de prestaties van ons clubke. Zoals een zin in het clublied luidt: Eendracht maakt macht. Hé, dat is eigenlijk nog de beste samenvatting van mijn betoog. Obesitaspreventie: Eendracht maakt macht

Wout en Koen, wat ben ik trots op jullie. En natuurlijk Joyce. Wat hou ik veel van jou. Ik heb vandaag verteld over hoe belangrijk de context is. En jij toont dat bij uitstek aan. Ik kan succesvol zijn in mijn werk omdat je niet alleen mij ondersteunt, maar ons hele gezin op jou steunt. Je bent eigenlijk mijn eigen hogere orde moderatortje. Ik heb wel eens betere koosnaampjes voor je bedacht, bedenk ik me nu, maar die houd je dan nog tegoed. Ik weet niet of $u$ wilde applaudisseren voor mijn rede, maar ik wil hierbij graag voorstellen dat als $u$ zo meteen applaudisseert, dat u dat niet voor mij doet, maar voor Joyce. Een applaus voor mijn context.

Dames en heren toehoorders:

Ik heb gezegd. 


\section{Referenties}

De Bruijn, G.J. (2007). Exploring individual-level and environmentallevel influences on energy balance-related behaviors: An integrative perspective. Dissertation, Maastricht University.

Egger, G., Swinburn, B. (1997). An ecological approach to the obesity pandemic. BMJ, 315, 477-480.

Friedman, S.L., Wachs, T.D. (1999). Measuring environment across the life span: Emerging methods and concepts. Washington, DC: American Psychological Association.

Gerards, S. (2014). Childhood obesity prevention. Rationale, implementation and effectiveness of the Lifestyle Triple P intervention. Dissertation, Maastricht University.

Gubbels, J.S. (2010). Influence of micro-environments on pre-school children's energy balance-related behaviours and weight status. Dissertation, Maastricht University.

Gubbels, J.S., Van Kann, D.H., de Vries, N.K., Thijs, C., Kremers, S.P. (2014). The next step in health behavior research: the need for ecological analyses - an application to diet and physical activity at childcare. International Journal of Behavioral Nutrition and Physical Activity, 11, 52.

Helmink, J.H.M., Gubbels, J.S., van Brussel-Visser, F.N., de Vries, N.K., Kremers, S.P.J. (2013). Baseline predictors of maintenance of interventioninduced changes in physical activity and sitting time among diabetic and pre-diabetic patients: a descriptive case series. BMC Research Notes, 6,190 .

Hendriks, A.M., Jansen, M.W.J., Gubbels, J.S., de Vries, N.K., Paulussen, T., Kremers, S.P.J. (2013). Proposing a conceptual framework for integrated local public health policy, applied to childhood obesity - the behavior change ball. Implementation Science, 8, 46 .

Kremers, S.P.J. (2010). Theory and practice in the study of influences on energy balance-related behaviors. Patient Education and Counseling, 79, 291-298. 
Kremers, S.P.J., de Bruijn, G.J., Visscher, T.L.S., van Mechelen, W., de Vries, N.K., Brug, J. (2006). Environmental influences on energy balance-related behaviors: A dual-process view. International Journal of Behavioral Nutrition and Physical Activity, 15, 3-9.

Kremers, S., Martens, M., Reubsaet, A., de Weerdt, I., de Vries, N., Jonkers, R. (2008). Programmeringstudie overgewicht. Zaandam: Kwak \& Van Daalen \& Ronday.

Milstein, B. (2006). Hygeia's constellation: navigating health futures in a dynamic and democratic world. Dissertation, Graduate College of Interdisciplinary Arts and Sciences, Union Institute \& University: Cincinatti, United States.

Rittel, H.W.J., Webber, M.M. (1973). Dilemmas in a general theory of planning. Policy Sciences, 4, 155-169.

Rodenburg, G. (2013). Family matters? Parental influences on primary school children's energy balance-related behaviours and weight. Dissertation, Erasmus University, Rotterdam.

Romon, M., Lommez, A., Tafflet, M., Basdevant, A., Oppert, J.M., Bresson, J.L., Ducimetiere, P., Charles, M.A., Borys, J.M. (2009). Downward trends in the prevalence of childhood overweight in the setting of 12-year school- and community-based programmes. Public Health Nutrition, 12, 1735-1742.

Rutten, G.M., Meis, J.J.M., Hendriks, M.R.C., Hamers, F., Veenhof, C., Kremers, S.P.J. (2014). The contribution of lifestyle coaching of overweight patients in primary care to more autonomous motivation for physical activity and healthy dietary behaviour: results of a longitudinal study. International Journal of Behavioral Nutrition and Physical Activity, 11, 86.

Scheffer, M. (2010). Complex systems: Foreseeing tipping points. Nature, $467,411-412$.

Sleddens, E.F.C. (2013). Childhood overweight. The influence of parenting on children's energy balance-related behavior. Dissertation, Maastricht University. 
Sleddens, E.F.C., Kroeze, W., Bolten, L, Brug, J., de Graaf, C., Kohl, L.F.M., Kremers, S. (2013). Kennissynthese Determinanten van voedingsgedrag. 's Hertogenbosch: Boxpress.

Thelen, E., Smith, L.B. (2006). Dynamic Systems Theories. In W. Damon (Editor-in-chief), R.M. Lerner (Ed.), Handbook of child psychology, Volume 1, Theoretical models of human development, 6th Edition (pp. 258-312). New York: Wiley.

Van Koperen, M.T.M., van der Kleij, R.M.J.J., Renders, C.M., Crone, M.R., Hendriks, A.M., Jansen, M.M., van de Gaar, V.M., Raat, H.J.H., Ruiter, E.L.M., Molleman, G.R.M., Schuit, A.J., Seidell, J.C. (2014). Design of CIAO, a research program to support the development of an integrated approach to prevent overweight and obesity in the Netherlands. BMC Obesity, 1:5.

Waddington $\mathrm{CH}$. The strategy of the genes. London: Allen \& Unwin, 1957. 
